\title{
Pemanfaatan Asap Cair Asal Limbah Padat Kelapa Sawit di Lahan Basah sebagai Bahan Insektisida Alami
}

\section{Utilization of Liquid Smoke Origin of Oil Palm Solid Waste in Wetland as A Natural Insecticide}

\author{
Samharinto Soedijo ${ }^{1 *}$, M. Indar Pramudi ${ }^{1}$, Helda Orbani Rosa ${ }^{1}$, \\ Ikhsan Maulana ${ }^{1}$, Priska Deyana Rima ${ }^{1}$, Gusti Muhammad Ahsin Anggarda Putra ${ }^{1}$ \\ ${ }^{1}$ Program Studi Proteksi Tanaman Fakultas Pertanian Universitas Lambung Mangkurat
}

Diterima: 09 September 2021 / Disetujui: 29 September 2021

\begin{abstract}
ABSTRAK
Pemanfaatan limbah padat kelapa sawit belum dilakukan secara maksimal, baru cangkang yang telah dimanfaatkan sebagai bahan bakar untuk broiler di pabrik pengolahan kelapa sawit, sedangkan limbah yang lainnya masih banyak yang belum dimanfaatkan. Limbah padat berupa tandan kosong, serabut dan cangkang tersebut dapat diolah menjadi asap cair dengan proses pirolisis. Mengingat terdapatnya potensi asap cair sebagai insektisida, maka dilakukan penelitian dengan tujuan untuk mempelajari pengaruh asap cair terhadap larva Spodoptera litura di laboratrium dan kemampuan asap cair untuk mengendalikan hama daun tanaman sawi, kedelai, dan hama polong kedelai. Penelitian dilakukan dengan rancangan acak lengkap. Metode sandwich daun dan semprot diujikan pada S. litura di laboratorium dan penyemprotan larutan asap cair pada sawi dan kedelai di lapangan. Hasil penelitian di laboratorium menunjukkan bahwa perlakuan asap cair metode semprot lebih mampu mematikan larva $S$. litura $(60 \%)$ dibandingkan dengan metode sandwich daun (16\%), metode sandwich daun lebih mampu menghambat pembentukan imago. Penelitian lapangan secara statistik antara perlakuan asap cair tidak menunjukkan perbedaan nyata terhadap intensitas kerusakan daun baik pada tanaman sawi maupun kedelai, perbedaan nyata hanya pada berat segar tanaman sawi.
\end{abstract}

Kata kunci: Asap cair, Insektisida alami, Limbah kelapa sawit

\section{ABSTRACT}

Utilization of palm oil solid waste has not been carried out optimally, only shells have been used as fuel for broilers in palm oil processing plants, while there are still many other wastes that have not been utilized. Solid waste in the form of empty fruit bunches and shells can be processed into liquid smoke by the pyrolysis process. Considering the potential of liquid smoke as an insecticide, a research was conducted with the aim of studying the effect of liquid smoke on Spodoptera litura larvae in the laboratory and the ability of liquid smoke to control leaf pests of mustard, soybeans, and soybean pods. The study was conducted with a completely randomized design. Leaf sandwich and spray methods were tested on S. litura in laboratory and spraying liquid smoke solution on mustard and soybeans in the field. The results of the research in the laboratory showed that the liquid smoke treatment with the spray method was more capable of killing S. litura larvae (60\%) compared to the leaf sandwich method (16\%), while the leaf sandwich method was more able to inhibit the formation of imago. Statisticaly field research between liquid smoke treatments did not show a significant difference in the intensity of leaf damage on both mustard and soybean plants, the only significant difference was in the fresh weight of mustard plants.

Keywords: Liquid smoke, Natural insecticide. Palm oil waste

*Penulis untuk korespondensi, E-mail : samharinto@ulm.ac.id

\section{PENDAHULUAN}

Kelapa sawit merupakan salah satu komoditi hasil perkebunan yang menjadi andalan Indonesia untuk mendatangkan devisa setiap tahun. Saat ini Indonesia merupakan produsen minyak kelapa sawit terbesar kedua di dunia setelah
Malaysia. Menurut laporan dari Global Agricultural Information Network (GAIN) USDA (2019) produksi minyak sawit Indonesia diperkirakan mencapai 43 juta ton pada 2019/20, meningkat 1,5 juta ton dari 2018/19. Sejalan dengan semakin meningkatnya produksi kelapa sawit dari tahun ke tahun, akan terjadi pula peningkatan volume 
limbahnya, baik berupa limbah padat maupun limbah cair. Limbah kelapa sawit adalah sisa-sisa hasil tanaman kelapa sawit yang tidak termasuk dalam produk utama atau merupakan hasil ikutan dari proses pengolahan kelapa sawit. Limbah padat kelapa sawit dapat berupa tandan kosong, cangkang, dan fiber (serabut). Limbah-limbah tersebut dihasilkan dari industri pengolahan kelapa sawit disamping dalam bentuk limbah cair (Pardamean, 2008).

Menurut BPS (2020) Areal perkebunan kelapa sawit tersebar di 26 Provinsi di Indonesia. Luas areal perkebunan kelapa sawit pada tahun 2019 sebesar 14.456.611 ha, sedangkan pada tahun 2021 diperkirakan terjadi peningkatan luas menjadi 15.081.21 ha (Direktorat jenderal Perkebunan, 2020). Tahun 2021 luas areal perkebunan kelapa sawi di Kalimantan Selatan 504.919 ha, lokasinya sendiri tersebar di berbagai lokasi baik di lahan kering maupun di lahan basah dengan demikian limbah yang dihasilkan semakin banyak, baik berupa limbah padat maupun cair dari proses pengolahan kelapa sawit. Pemanfaatan limbahlimbah tersebut belum dilakukan secara maksimal, baru cangkang yang telah dimanfaatkan sebagai bahan bakar untuk broiler di pabrik pengolahan kelapa sawit. Setiap pabrik dengan kapasitas 60 ton/jam dapat mengolah tandan buah segar (TBS) hingga 1000 ton/hari (Rahardjo, 2009), dan setiap pengolahan TBS menjadi CPO menghasilkan limbah antara lain 23\% tandan kosong kelapa sawit (TKKS); 6,5\% cangkang dan 13\% serat (Direktorat Jenderal Perkebunan, 2020). Salah satu alternatif solusi penanganan limbah ini adalah memproses limbah tersebut menjadi asap cair melalui teknik pirolisis.

Teknik pirolisis terhadap limbah padat kelapa sawit dapat mengolah limbah tersebut secara cepat menghasilkan produk berupa arang dan asap. Asap yang dikeluarkan dapat dicairkan menjadi destilat (asap cair). Asap cair adalah produk yang diperoleh dari proses dekomposisi kimia bahan organik dengan memanaskan di ruangan dengan kekurangan atau tanpa oksigen untuk memutuskan ikatan molekul kompleks menjadi ikatan molekul yang lebih kecil (Czernik \& Bridgewater, 2004; Awaludin, 2007). Asap cair mengandung beberapa senyawa seperti senyawa fenolik yang berfungsi sebagai insektisida sehingga dapat menjadi bahan alami untuk mengatasi masalah hama (Tiilikkala et al., 2010; Tiilikkala et al. 2011).

Saat ini, penelitian tentang penggunaan asap cair sudah berkembang terutama dengan memanfaatkan limbah pertanian. Asap cair limbah batang tembakau dan tempurung kelapa bersifat insektisida terhadap larva $S$. litura (Prabowo et al., 2016; Isa et al., 2019), asap cair sampah organik mengandung senyawa antifeedant terhadap $S$. litura (Haji et al., 2012), dan asap cair sabut kelapa bersifat repelen bagi Leptocorisa oratorius (Santoso, 2015), sedangkan pemanfaatan asap cair limbah kelapa sawit untuk pengendalian hama dan penyakit masih terbatas pada asap cair yang berasal dari tandan kosong (Oramahi et al., 2010; Sari et al., 2018; Listisio, 2020), sementara pemanfaatan asap cair yang berasal dari cangkang, serabut dan tandan kosong kelapa sawit belum banyak dilaporkan.

Penelitian ini bertujuan mempelajari potensi larutan asap cair sebagai insektisida di laboratorium dan untuk mengendalikan hama daun tanaman sawi, kedelai dan hama polong kedelai.

\section{BAHAN DAN METODE}

Penelitian dilakukan dari bulan Oktober hingga Nopember 2020, yang meliputi percobaan di laboratorium dan di lapangan. Penelitian di laboratorium dengan memberikan perlakukan pada serangga uji $S$ litura sedangkan di lapangan dengan memberikan perlakuan pada tanaman sawi dan kedelai.

Rancangan percobaan untuk kedua percobaan tersebut digunakan rancangan acak lengkap. Perlakuan yang diberikan untuk percobaan di lapangan adalah tiga jenis asap cair dari limbah yaitu cangkang $(\mathrm{C})$, serabut (S) dan tandan kosong (T) dengan konsentrasi masing-masing 7,5\%, pestisida kimia bahan aktif Abamectin 18g/l dengan konsentrasi larutan 2\% dan air sebagai kontrol. Untuk percobaan yang di laboratorium, perlakuan yang diberikan sama dengan yang di lapangan kecuali perlakuan pestisida kimia. Setiap perlakuan diulang 5 kali. Percobaan di laboratorium dengan menggunakan serangga uji larva dari Spodoptera litura sebanyak 10 ekor persatuan percobaan. Percobaan di lapangan diawali dengan mempersiapkan pertanaman. Sebelum dilakukan penanaman, lahan diolah dengan alat pengolah tanah bermesin (cultivator), kemudian dibuat petakpetak sebagai satuan percobaan dengan ukuran petak $1 \mathrm{~m} \times 1 \mathrm{~m}$. Untuk tanaman sawi dilakukan terlebih dahulu penyemaian dan dipindahkan setelah bibit berumur \pm 20 hari, sedangkan tanaman kedelai langsung ditanam.

Aplikasi asap cair di lapangan pada tanaman sawi dan kedelai dilakukan dengan interval 4 hari hingga menjelang panen dengan volume smperot $50 \mathrm{ml}$ larutan per petak. 
Perlakuan yang dilakukan sebagai berikut:

\begin{tabular}{|c|c|}
\hline Kor & Kontrol (tanpa perlakuan). \\
\hline $\operatorname{Kimia}(\mathrm{Km})$ & $\begin{array}{l}\text { Perlakuan insektisida sintetis } \\
\text { (bahan aktif Abamectin } \\
18 \mathrm{~g} / \mathrm{l} \text { ) dengan konsentrasi } \\
\text { larutan } 2 \% \text {. }\end{array}$ \\
\hline Cangkang (C) & $\begin{array}{l}\text { Perlakuan asap cair dari } \\
\text { cangkang kelapa sawit } \\
\text { dengan konsentrasi larutan } \\
7,5 \% \text {. }\end{array}$ \\
\hline Serabut (S) & $\begin{array}{l}\text { Perlakuan asap cair dari } \\
\text { serabut kelapa sawit dengan } \\
\text { konsentrasi larutan } 7,5 \% \text {. }\end{array}$ \\
\hline $\begin{array}{l}\text { Tandan } \\
\text { kosong }(\mathrm{T})\end{array}$ & $\begin{array}{l}\text { Perlakuan asap cair dari } \\
\text { jenjang kelapa sawit dengan } \\
\text { konsentrasi larutan } 7,5 \% \text {. }\end{array}$ \\
\hline
\end{tabular}

\section{Pengujian di laboratorium}

Pengujian pengaruh terhadap serangga uji (larva S. litura) dilakukan dengan metode sandwich daun (tidak langsung) dan metode semprot (langsung). Metode sandwich daun dilakukan dengan memberikan daun berukuran 5 x $5 \mathrm{~cm}$ sebanyak 20 lembar yang telah dicelup ke dalam larutan asap cair dengan konsentrasi sesuai dengan perlakuan.. Kemudian dikering anginkan, selanjutnya diberikan kepada serangga uji (10 ekor persatuan percobaan dari setiap perlakuan). Sedangkan metode semprot dilakukan penyemperotan larutan asap cair ke tubuh larva $S$. litura hingga membasahi tubuh larva dengan konsentrasi larutan sesuai perlakuan Variabel pengamatan pada pengujian di laboratorium meliputi persentase mortalitas larva, persentase larva menjadi pupa, dan persentase pupa menjadi imago merujuk dengan metode Hasnah et al.( 2012).

Untuk mengetahui persentase mortalitas dilakukan penghitungan kematian terhadap larva setelah diberikan perlakuan larutan asap cair dengan menggunakan rumus berikut.

$$
\mathrm{P}=\mathrm{A} / \mathrm{B} \times 100 \%
$$

Dimana $\mathrm{P}=$ Persentase moratlitas; $\mathrm{A}=$ Jumlah larva yang mati dan $B=$ Jumlah keseluruhan larva yang diamati.

Pengamatan persentase larva menjadi pupa dan pupa menjadi imago dengan menggunakan rumus berikut.

$$
\mathrm{P}=\mathrm{A} / \mathrm{B} \times 100 \%
$$

Dimana $\mathrm{P}=$ Persentase larva menjadi pupa atau pupa menjadi imago; $\mathrm{A}=$ Jumlah larva yang menjadi imago atau pupa menjadi imago dan $\mathrm{B}=$ Jumlah keseluruhan pupa atau larva yang diamati.

\section{Pengujian di lapangan}

Variabel yang diamati adalah intensitas serangan hama pada daun tanaman sawi dan kedelai dan polong, serta jumlah polong kedelai. Rumus yang digunakan dalam menghitung intensitas serangan pada daun masing-masing tanaman uji sebagai berikut (Natawigena, 1985):

$$
\mathrm{I}=\frac{\sum_{i=0}^{Z}\left(n_{\mathrm{i}} x v_{i}\right)}{Z X N} X 100 \%
$$

Dimana $\mathrm{I}=$ intensitas kerusakan; $\mathrm{n}_{\mathrm{i}}=$ jumlah daun yang rusakdengan skala kerusakan $\mathrm{v}_{\mathrm{i}}$; $\mathrm{v}_{\mathrm{i}}=$ nilai skala kerusakan contoh ke-I; $\mathrm{N}=$ jumlah daun tanaman contoh yang diamati dan $\mathrm{Z}=$ nilai skala kerusakan tertinggi.

Skala kerusakan $0=$ tidak ada kerusakan daun tanaman; $1=$ terdapat kerusakan daun sebesar $\leq$ $25 \% ; 2=$ terdapat kerusakan sebesar antara $>25-$ $\leq 50 \% ; 3=$ terdapat kerusakan sebesar antara $>$ $50 \%-\leq 75 \%$ ) dan $4=$ terdapat kerusakan $>75 \%$.

Untuk menentukan intensitas serangan polong digunakan rumus berikut:

$$
\mathrm{P}=\mathrm{A} / \mathrm{B} \times 100 \%
$$

Dimana P : Persentase kerusakan polong; A : Jumlah polong yang rusak; dan B : Jumlah polong keseluruhan yang diamati.

\section{Analisis data}

Data hasil pengamatan selanjutnya dianalisis menggunakan sidik ragam pada jenjang $5 \%$, apabila ada pengaruh nyata dilakukan uji lanjut menggunakan uji beda nyata terkecil (BNT) $5 \%$.

\section{HASIL DAN PEMBAHASAN}

\section{Pengujian di laboratorium}

Hasil uji Duncan dari analisis ragam data di laboratorium, pemberian asap cair limbah kelapa sawit berupa cangkang $(\mathrm{C})$, serabut (S) dan tandan kosong $(\mathrm{T})$ dengan menggunakan metode sandwich daun dan metode semprot. Hasil uji lanjut menunjukan bahwa perlakuan metode sandwich daun yang diberikan tidak memberikan pengaruh nyata terhadap persentase mortalitas larva, persentase pupa yang terbentuk dan persentase imago yang terbentuk, sedangkan pada metode semprot hanya persentase mortalitas larva yang menunjukkan adanya pengaruh sangat nyata dari perlakuan yang diberikan (Tabel 1). 
Tabel 1. Hasil F-hitung semua variabel yang diamati

\begin{tabular}{|c|c|c|}
\hline \multirow{2}{*}{ Variabel } & \multicolumn{2}{|c|}{ F. Hitung } \\
\hline & Metode sandwich daun & Metode Semprot \\
\hline Persentase mortalitas larva $S$. Litura & $0,48^{\mathrm{ns}}$ & $22,38^{* *}$ \\
\hline Larva menjadi pupa & $0,62^{\mathrm{ns}}$ & $2,77^{\mathrm{ns}}$ \\
\hline Pupa menjadi imago & $1,34^{\mathrm{ns}}$ & $0,02^{\mathrm{ns}}$ \\
\hline
\end{tabular}

Keterangan: $* *=$ berbeda sangat nyata, ns $=$ non signifikan dengan uji beda nyata terkecil (BNT) $5 \%$

\section{Mortalitas larva S. litura}

Perlakuan asap cair limbah kelapa sawit memperlihatkan pengaruh tidak nyata terhadap mortalitas $S$. litura pada metode sandwich daun dan persentase kematian hanya mencapai $16 \%$ pada pengamatan hari ke-5 (Tabel 2), sedangkan pada metode semprot, perlakuan memperlihatkan pengaruh sangat nyata dibandingkan kontrol (air) dengan persentase tertinggi $60 \%$ (Tabel 3), meskipun antar perlakuan sendiri tidak terlihat adanya pengaruh yang berbeda.

Tabel 2. Rata-rata persentase mortalitas larva S. litura pada metode sandwich daun

\begin{tabular}{lcccc}
\hline \multirow{2}{*}{ Perlakuan } & \multicolumn{4}{c}{ Persentase mortalitas larva (\%) } \\
\cline { 2 - 5 } & Hari ke-2 & Hari ke-3 & Hari ke-4 & Hari ke-5 \\
\hline C (larutan asap cair cangkang) & 2,0 & 6,0 & 12,0 & 12,0 \\
S (larutan asap cair serabut) & 4,0 & 6,1 & 8,0 & 14,0 \\
T (larutan sap cair tandan kosong) & 0,1 & 2,0 & 14,0 & 16,0 \\
K (kontrol) & 0,2 & 6,2 & 8,1 & 10,0 \\
\hline
\end{tabular}

Tabel 3. Rata-rata persentase mortalitas larva S. litura pada metode semprot

\begin{tabular}{lrrrr}
\hline \multirow{2}{*}{ Perlakuan } & \multicolumn{4}{c}{ Persentase mortalitas larva (\%) } \\
\cline { 2 - 5 } & Hari ke-2 & Hari ke-3 & Hari ke-4 & Hari ke-5 \\
\hline C (larutan asap cair cangkang) & $10,0^{\mathrm{b}}$ & $28,0^{\mathrm{bc}}$ & $40,0^{\mathrm{b}}$ & $48,0^{\mathrm{b}}$ \\
S (larutan asap cair serabut) & $14,0^{\mathrm{b}}$ & $26,0^{\mathrm{b}}$ & $40,1^{\mathrm{b}}$ & $54,0^{\mathrm{bc}}$ \\
T (larutan sap cair tandan kosong) & $20,0^{\mathrm{c}}$ & $36,0^{\mathrm{c}}$ & $46,0^{\mathrm{b}}$ & $60,0^{\mathrm{c}}$ \\
K (kontrol) & $2,0^{\mathrm{a}}$ & $4,0^{\mathrm{a}}$ & $4,0^{\mathrm{a}}$ & $4,0^{\mathrm{a}}$ \\
\hline
\end{tabular}

Keterangan : Rata-rata yang diikuti hurup yang sama pada kolom yang sama menunjukkan berbeda tidak nyata (BNT) pada uji beda nyata terkecil (BNT) taraf 5\%

Berdasarkan tabel di atas menunjukkan bahwa pemberian asap cair dengan metode semprot (langsung) lebih mampu membunuh larva dibandingkan metode sandwich daun, hal serupa juga dilaporkan oleh Prabowo et al., (2016). Aktivitas asap cair ini belum dapat dikatakan efektif karena belum mampu mematikan minimal $80 \%$ larva S. litura (Mumford \& Norton, 1984), meskipun demikian aktivitas asap cair ini masih masuk dalam kategori sedang (Prijono, 1998 dalam Utami \& Haneda, 2010). Kemampuan mematikan yang belum mampu mencapai $80 \%$ ini diduga disebabkan oleh dosis yang digunakan terlalu rendah (sublethal) sehingga tidak langsung bereaksi. Konsentrasi sublethal asap cair limbah batang tembakau juga pernah dilaporkan tidak menyebabkan kematian larva $S$. litura tetapi mampu menghambat pertumbuhannya (Prabowo et al., 2016).

Pada metode semprot, senyawa racun yang terdapat dalam asap cair tersebut masuk ke jaringan tubuh larva melalui kulit, mulut, atau trakea dan menembus integumen sehingga dapat langsung menyebabkan kematian larva. Beberapa senyawa yang terdapat dalam asap cair limbah kelapa sawit seperti asam asetat dan asam benzoate (benzensulfonic acid/carbamic acid) ( Sari et al., 2018) memiliki sifat mudah larut dalam dalam air 
(Kemenlhk, 2015; Wardiyah, 2016) sehingga bahan aktif lebih cepat masuk ke dalam tubuh serangga, menghemolisis sel darah, merusak fungsi sel dan dapat menyebabkan kematian larva. Knobloch et al. (1989) menyatakan bahan aktif yang memiliki kelarutan tinggi dalam air akan mudah menembus lapisan fosfolipid membran sel sehingga lebih cepat mengganggu fungsi fisiologis yang pada akhirnya sel akan mengalami kematian. Larva yang mati berwarna hitam, kering mengkerut dan ada pula yang menguning membusuk dengan kondisi lembek/basah.

\section{Persentase pupa yang terbentuk}

Rata-rata persentase larva yang mampu menjadi pupa pada metode semprot cenderung lebih rendah dibanding metode sandwich daun (Tabel 4), artinya kemampuan penghambatan perkembangan larva lebih bagus. Larva yang tidak mengalami kematian pada pengamatan hari ke-5 (metode semprot) ternyata mengalami penghambatan dalam perkembangannya untuk menjadi pupa. Pupa yang terbentuk hanya $\pm 50 \%$ ini menunjukkan bahwa kegagalan larva yang menjadi pupa karena adanya senyawa toksik yang terkandung dalam asap cair yang mampu menghambat perkembangannya. Senyawa toksik tersebut diduga masih terkandung pada tubuh larva yang masih hidup, terbawa hingga mempengaruhi perkembangan larva ke fase berikutnya yaitu pupa.

Rendahnya persentase pupa yang terbentuk juga dipengaruhi oleh jumlah larva yang mati saat pengaplikasian asap cair. Saat pengaplikasian kematian larva pada metode semprot mencapai $60 \%$ karena banyaknya larva yang mati maka terbentuknya pupa juga semakin sedikit (Agazali, 2015; Firdaus, 2016).

Kegagalan larva menjadi pupa diduga juga dapat disebabkan oleh penggunaan dosis yang subletal, seperti yang dikemukakan Priyono (1988) dalam Hasnah et al.(2012) bahwa serangga yang terkena insektisida dalam konsentrasi sublethal tidak mematikan, tetapi dapat menyebabkan perubahan fisiologis dan perilaku, sehingga dapat menghambat pertumbuhan termasuk gagalnya pupa.

Kegagalan larva pada tahap perkembangan menjadi pupa dapat dikenali dari beberapa tanda, larva yang gagal dalam proses penggantian kulit menuju pupa, cenderung basah/lembek, dan larva instar terakhir mengering dan mengkerucut pada proses mendekati pelepasan kulit menjadi pupa.

\section{Persentase imago yang terbentuk}

Kemampuan pupa menjadi imago rata-rata lebih rendah pada metode sandwich daun $(43,4 \%$ $68,0 \%$ dibandingkan dengan metode semprot $(90,0 \%$ - 92,1\%), artinya metode sandwich daun lebih mampu menghambat pembentukan imago. Pada metode sandwich daun, senyawa toksik masuk ke pencernaan melalui makanan yang mereka makan. Pada saat larva $S$. litura memakan daun yang sebelumnya dicelupkan ke dalam asap cair, maka senyawa toksik yang terdapat pada permukaan daun juga ikut masuk ke dalam tubuh larva namun tidak secara langsung menyebabkan kematian yang tinggi pada larva seperti pada metode semprot karena perlu waktu untuk dapat mengakibatkan terganggunya alat pencernaan larva tersebut sehingga larva masih dapat berkembang ke fase berikutnya namun pada akhirnya akan mati atau tidak mampu membentuk imago.

Penggunaan dosis subletal juga dapat menyebabkan aktivitas peracunan berjalan agak lambat, seperti hasil penelitian yang dilakukan oleh Rifai et al, (2016) bahwa toksisitas konsentrasi subletal dapat meningkat beberapa jam/hari setelah aplikasi. Rata-rata persentase pupa yang mampu menjadi imago pada metode sandwich dan semprot masing-masing berkisar antara $43,4 \%-68 \%$ dan 90\% - 92,1\% (Tabel 5).

Tabel 4. Rata-rata persentase pupa yang terbentuk pada metode sandwich daun dan semprot

\begin{tabular}{|c|c|c|}
\hline \multirow{2}{*}{ Perlakuan } & \multicolumn{2}{|c|}{ Persentase pupa yang terbentuk } \\
\hline & Metode sandwich daun & Metode Semprot \\
\hline C (larutan asap cair cangkang) & 68,0 & 52,0 \\
\hline S (larutan asap cair serabut) & 68,1 & 46,0 \\
\hline $\mathrm{T}$ (larutan asap cair tandan kosong) & 57,0 & 40,0 \\
\hline $\mathrm{K}$ (kontrol) & 76,0 & 78,0 \\
\hline
\end{tabular}

Pupa yang gagal menjadi imago memperlihatkan bentuk yang tidak sempurna (malformation). Pupa berbentuk oval mengerucut dan tidak tumbuh dengan baik, juga ada pupa yang berbentuk lonjong, mengering dan terlihat imago yang gagal keluar dari pupa. 


\section{Pengujian di lapangan}

Hasil analisis ragam menunjukan bahwa perlakuan asap cair yang diberikan tidak memberikan pengaruh nyata terhadap intensitas serangan hama daun sawi, intensitas serangan hama daun kedelai, intensitas serangan hama polong kedelai dan jumlah polong kedelai, pengaruh nyata dari perlakuan yang diberikan hanya terlihat pada berat segar sawi (Tabel 6).

\section{Intensitas serangan hama dan jumlah polong}

Aplikasi asap cair limbah kelapa sawit berupa cangkang, tandan, dan serabut pada tanaman sawi dan kedelai tidak memperlihatkan adanya pengaruh nyata terhadap intensitas serangan hama pada daun sawi, daun kedelai dan polong kedelai dan jumlah polong baik terhadap antar perlakuan asap cair maupun tanpa perlakuan (kontrol kimia dan air). Hal ini diduga konsentrasi 7,5 \% yang digunakan pada penelitian ini masih terlalu rendah sehingga belum mampu memberikan pengaruh terhadap parameter-parameter tersebut, meskipun konsentrasi ini pada penelitian Sari et al. (2018) memberikan pengaruh sangat nyata. Banyak faktor yang dapat mempengaruhi efektifitas penggunaan asap cair meskipun itu dalam konsentrasi dan bahan yang sama, salah satunya adalah kualitas asap cair yang digunakan. Kualitas asap cair tergantung pada jenis bahan baku, suhu pirolisis, ukuran partikel bahan, dan kadar air bahan baku (Choi et al., 2015; Crespo et al., 2017; Oramahi, 2020). Sehingga kemungkinan konsentrasi yang digunakan dalam penelitian ini kurang efektif disebabkan oleh salah satu atau beberapa dari faktor yang mempengaruhi kualitas asap cair tersebut.

Tabel 5. Rata-rata persentase imago yang terbentuk pada metode sandwich daun dan semprot

\begin{tabular}{|c|c|c|}
\hline \multirow{2}{*}{ Perlakuan } & \multicolumn{2}{|c|}{ Persentase imago yang terbentuk } \\
\hline & Metode sandwich daun & Metode Semprot \\
\hline C (larutan asap cair cangkang) & 50,0 & 90,1 \\
\hline S (larutan asap cair serabut) & 48,2 & 90,0 \\
\hline $\mathrm{T}$ (larutan asap cair tandan kosong) & 43,4 & 92,0 \\
\hline K (kontrol) & 68,0 & 92,1 \\
\hline
\end{tabular}

Tabel 6. Hasil F-hitung dan P-Value semua variabel yang diamati

\begin{tabular}{lcc}
\hline Variabel Pengamatan & F. Hitung & P-Value \\
\hline Intensitas serangan daun sawi & $1,41^{\mathrm{ns}}$ & 0,262 \\
Intensitas serangan daun kedelai & $2,47^{\mathrm{ns}}$ & 0,072 \\
Intensitas serangan polong kedelai & $0,55^{\mathrm{ns}}$ & 0,699 \\
Jumlah polong kedelai & $1,71^{\mathrm{ns}}$ & 0,181 \\
Berat segar sawi & $2,97^{*}$ & 0,040 \\
\hline
\end{tabular}

Keterangan: $\mathrm{ns}=$ tidak berbeda nyata (non significant). $*=$ berbeda nyata pada uji beda nyata terkecil $(\mathrm{BNT})$ taraf $5 \%$

\section{Berat segar sawi}

Perlakuan yang diujikan menunjukkan adanya pengaruh nyata terhadap berat segar (gram) tanaman sawi. Berat segar rata-rata pada masingmasing perlakuan dan hasil analisis beda nilai tengah dapat dilihat pada grafik dibawah ini (Gambar 4).

Hasil perhitungan berat segar tanaman sawi pada kontrol lebih rendah hanya sebesar 835 gram dibandingkan dengan perlakuan asap cair, pada perlakuan cangkang 1060 gram, perlakuan tandan kosong 890 gram dan perlakuan serabut 1010 gram, ini menunjukkan bahwa aplikasi asap cair telah meningkatkan pertumbuhan tanaman sawi. Hal ini disebabkan oleh adanya senyawa dalam asap cair yang mampu meningkatkan pertumbuhan tanaman dan berpotensi sebagai pupuk organik. Yatagai (2002) dan Muhakka et.al (2013) menyatakan bahwa asap cair limbah kelapa sawit berpotensi mempercepat pertumbuhan tanaman karena memiliki kandungan metanol dan asam asetat yang berperan memproses percepatan tumbuhan. Nurhayati (2007) juga menyebutkan bahwa asap cair dengan konsentrasi $2 \%$ ternyata dapat meningkatkan pertumbuhan padi dan dapat meningkatkan produksi gabah kering panen sebesar 
33\%. Asap cair tandan kosong kelapa sawit dapat dijadikan sebagai pupuk cair organik karena memiliki senyawa yang dibutuhkan tanaman dalam pertumbuhan seperti Ca, C, N dan P (Sulaeman, et al., 2013).

Pemberian asap cair limbah kelapa sawit berupa cangkang, tandan dan serabut dengan konsentrasi $7,5 \%$ pada $S$. litura di laboratorium dengan metode semprot memberikan pengaruh yang sangat nyata dengan kematian larva mencapai $60 \%$ meskipun belum dapat dikatakan efektif, namun dengan konsentrasi yang sama pada pengujian di lapangan tidak memperlihatkan adanya pengaruh nyata terhadap semua parameter yang diamati kecuali pada berat sawi sehingga untuk penelitian berikutnya sebaiknya untuk aplikasi di lapangan konsentrasi lebih ditingkatkan juga penting untuk memperhatikan faktor-faktor yang dapat mempengaruhi kualitas asap cair hasil pirolisis.

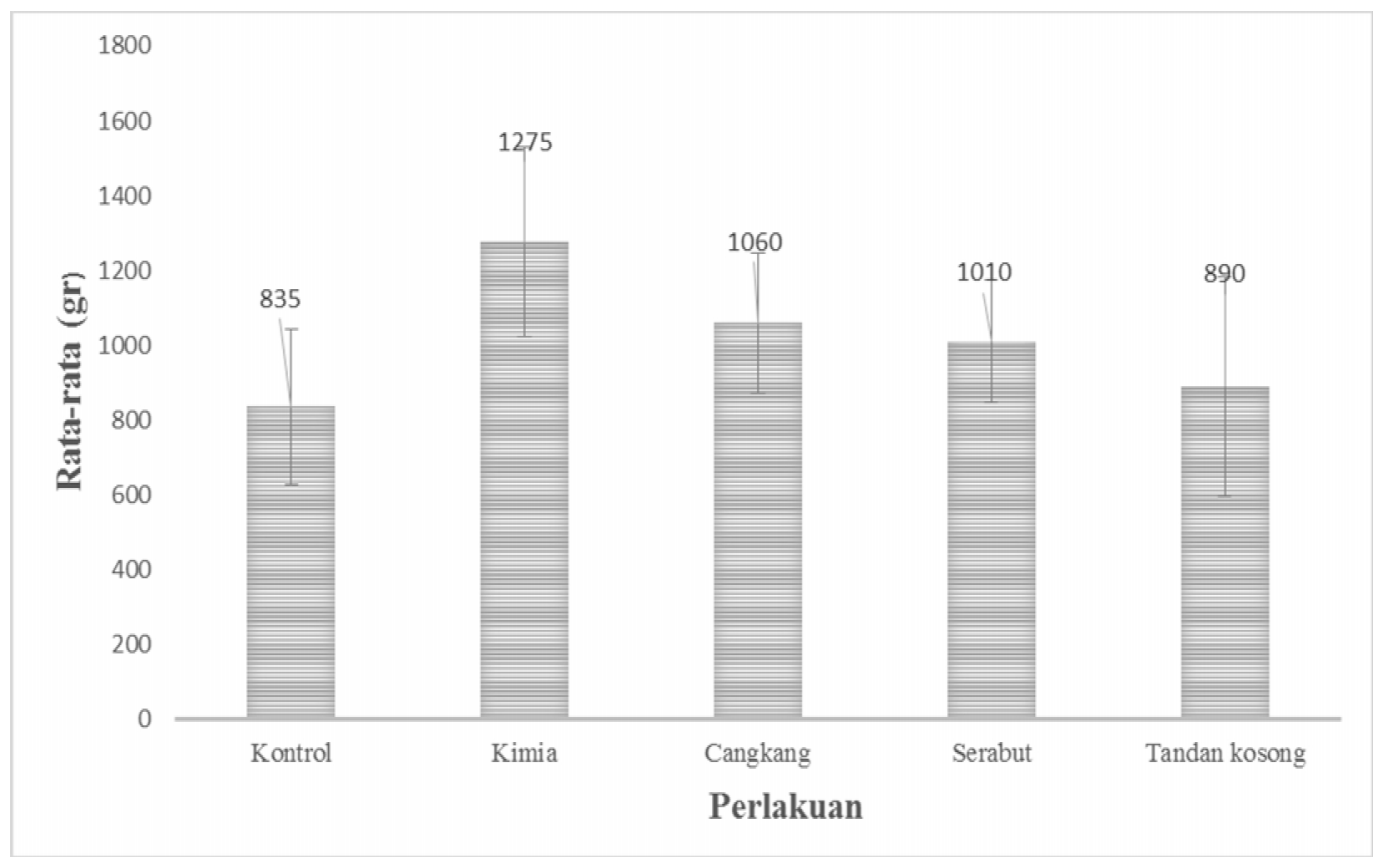

Keterangan: Angka yang diikuti huruf yang berbeda menunjukkan berbeda nyata pada uji beda nyata terkecil (BNT) taraf 5\%

Gambar 4. Grafik rata-rata berat segar tanaman sawi setelah diberi perlakuan asap cair limbah padat kelapa sawit

\section{KESIMPULAN}

Penggunaan larutan asap cair dengan metode semprot lebih efektif dibandingkan metode sandwich daun di laboratorium dengan persentase kematian larva $S$. litura $60 \%$ berbanding $16 \%$. Sedangkan percobaan di lapangan baik pada tanaman sawi maupun kedelai, larutan asap cair tidak berpengaruh antar perlakuan.

\section{DAFTAR PUSTAKA}

Agazali, F., M. Hoesain \& S. Prastowo. 2015. Efektivitas Insektisida Nabati Daun Tanjung dan Daun Pepaya Terhadap Mortalitas Ulat Grayak (Spodoptera litura F.). Berkala Ilmiah Pertanian 1(1):1-5.

Awaludin, A. 2007. Proses Pencairan Langsung Biomassa menjadi Bio-oil dengan menggunakan Thermo-Oil. Proposal I-MHERE Project. HEI-UI Universitas. Riau.

Badan Pusat Statistik (BPS). 2020. Statistik Kelapa Sawit Indonesia 2019. $137 \mathrm{hlm}$.

Czernik, S. \& A. V. Bridgwater. 2004. Overview of Applications of Biomass Fast Pyrolysis Oil. Energy\& Fuels 18: 590-598

Choi, G.G., S. J. Oh, S. J. Lee, \& J. S. Kim. 2015, Production of bio-based phenolic resin and activated carbon from bio-oil and biochar derived from fast pyrolysis of palm kernel shells, Bioresour. Technol., 178, 99-107. https://doi.org/10.1016/j.biortech.2014.08.053

Crespo, Y.A., R. A. Naranjo, Y. G. Quitana, C. G. Sanchez, \&, E. M. S. Sanchez. 2017. Optimisation and characterisation of bio-oil 
produced by Acacia mangium Willd wood pyrolysis. Wood Sci. Technol., 51 (5), 11551171.

Direktorat Jenderal Perkebunan. 2020. Statistik Perkebunan Indonesia 2018-2020. Kementerian Pertanian.

Direktorat Jenderal Perkebunan. 2020. Luas Areal Kelapa Sawit Menurut Provinsi di Indonesia, 2018-2020. Data Sensus.

Firdaus, S.U. 2016. Uji Efektifitas Beberapa Konsentrasi Larutan Daun Kirinyuh (Choromolaena odorata (L.) King \& Robinson) terhadap Ulat Tritip (Plutella Xylostella L) Pada Tanaman Kubis (Brassica oleraceae Var. Capitata) Di Laboratorium. Jurnal Agribisnis 18(2):132-141.

Haji, A. Z. A. Gani, Mas'ud, \& G. Pari. 2012. Identifikasi Senyawa Bioaktif Antifeedant dari Asap Cair Hasil Pirolisis Sampah Organik Perkotaan. Jurnal Bumi Lestari. 12(1): 1-8.

Hasnah, Husni, \& A. Fardhisa. 2012. Pengaruh Ekstrak Rimpang Jeringau (Acorus calamus L.) terhadap Mortalitas Ulat Grayak Spodoptera litura F. J. Floratek 7:115-124.

Isa, I., W.J.A. Musa \& S.W Rahman. 2019. Pemanfaatan Asap Cair Tempurung Kelapa Sebagai Pestisida Organik Terhadap Mortalitas Ulat Grayak (Spodoptera liitura F.). Jamb. J.Chem. 01(1):15-20.

Kemenlhk (Kementerian lingkungan hidup dan kehutanan). 2015. Kuning metanil (metanil yellow)

http://sib3pop.menlhk.go.id/index.php/bepo $\mathrm{p} /$ view?slug $=$ diklorfos diakses 21 Juni 2021.

Knobloch, K., A. Pauli, B. Iberl, H. Weigand, \& N. Weis. 1989. Anti bacterial and antifungal Properties of Essential oil Components. $J$. Ess. Oil Res. 1(3):119-128

Lististio, D. 2020. Uji efektivitas asap cair tandan kelapa sawit untuk mengendalikan Ganoderma boninense dan Curvularia sp. secara invitro. Skripsi. UIN SUSKA RIAU.

Muhakka, A. Napoleon. \& H. Isti'adah. 2013. Pengaruh Pemberian Pupuk Cair terhadap Kandungan NDF. Jurnal Peternakan Sriwijaya. 3(1): 47-54
Mumford, J. D. \& G. A. Norton. 1984. Economics of decision making in pestmanagement. Ann. Rev. Entomol. 29;157-174.

Natawigena, H. 1985. Pestisida dan Kegunaannya. CV. Armico. Bandung.

Nurhayati. 2007. Asap Cair dan Penggunaannya dalam Pertanian. Gramedia. Jakarta.

Oramahi, H.A. 2020. Produksi Asap Cair dan Potensinya sebagai Bahan Anti Jamur ed Farah diba. Penerbit GAVA MEDIA, Yogyakarta. $76 \mathrm{hlm}$.

Oramahi, H. A. \& F. Diba. 2010. Efikasi Asap Cair Dari Tandan Kosong Kelapa Sawit (TKKS) dalam Penekanan Perkembangan Jamur Aspergillus Niger. Jurnal Hama dan Penyakit Tumbuhan Tropika. 10(2): 146153.

Pardamean, M. 2008. Panduan Lengkap Pengelolaan Kebun dan Pabrik Kelapa Sawit. Agromedia Pustaka. Jakarta.

Prabowo, H., Martono, E., \& Witjaksono, W. 2016. Activity of Liquid Smoke of Tobacco Stem Waste as An Insecticide on Spodoptera litura Fabricius Larvae. Jurnal Perlindungan Tanaman Indonesia. 20(1): 22-27. DOI: 10.22146/jpti.16620

Rahardjo, P. N. (2009). Studi Banding Teknologi Pengolahan Limbah Cair Pabrik Kelapa Sawit. J. Tek. Ling, 10(1), 09-18.

Rifai, Hasriyanty \& B. Nasir. 2016. Efikasi Dua Jenis Ekstrak Tumbuhan dan kombonasi keduanya terhadap mortalitas hama ulat bawang merah (Spodoptera exigua Hubn). Jurnal Agrotekbis 4 (6) : $684-692$.

Santoso, R. S. 2016. Asap Cair Sabut Kelapa sebagai Repelan Bagi Hama Padi Walang Sangit (Leptocorisa oratorius). Sainsmat. 4(2): 81-86.

Sari Y.P, Samharinto \& B.F Langai. 2018. Penggunaan Asap Cair Tandan Tosong Kelapa Sawit (TKKS) sebagai Pestisida Nabati untuk Mengendalikan Hama Perusak Daun Tanaman Sawi (Brassica junsea L). EnviroScienteae, 14(3):278-284.

Sulaeman, R., R. Rustam. \& G. M. E. Manurung. 2013. Tandan Kosong Sawit Sebagai Bahan Baku Asap Cair (Liquid Smoke). Prosiding Seminar Nasional. Pekanbaru 
J. Berkala Penelitian Agronomi 9 (2) : 96 - 104 (2021)

Tiilikkala, K., L. Fagernäs, \& J. Tiilikkala. 2010. History and Use of Wood Pyrolysis Liquids as Biocide and Plant Protection Product. The Open Agriculture Journal 4: 111-118.

Tiilikkala, K., I. Lindqvist, M. Hagner, H. Setälä, \& D. Perdikis. 2011. Use of Botanical Pesticides in Modern Plant Protection. Pesticides in the Modern World-Pesticides Use and management. 259-272. DOI: $10.5772 / 17737$

Utami, S \& N.F. Haneda. 2010. Pemanfaatan Etnobotani dari Hutan Tropis Bengkulu sebagai Pestisida Nabati. JMHT 16 (3): 143-147.

USDA. 2019. Indonesia Oilseeds and Products Annual Indonesia Oilseeds and Products Annual 2019. Global Agricultural Information Network (GAIN). GAIN Report Number:ID1903. 16 pp.

Wardiyah. 2016. Modul Kimia Organik. Pusdik SDM Kesehatan. Jakarta. $217 \mathrm{hlm}$.

Yatagai. 2002. Kandungan Asap Cair. Pustaka Mahardika. Yogyakarta. 